\title{
Influence of $\delta$-Opioid Receptors in the Behavioral Effects of Nicotine
}

\author{
Fernando Berrendero ${ }^{1,3}$, Ainhoa Plaza-Zabala ${ }^{1,3}$, Lola Galeote ${ }^{1,3}$, África Flores ${ }^{1,3}$, S Andreea Bura', \\ Brigitte L Kieffer ${ }^{2}$ and Rafael Maldonado*, I \\ 'Department of Experimental and Health Sciences, Laboratory of Neuropharmacology, Universitat Pompeu Fabra, PRBB, Barcelona, \\ Spain; 'Département de Médecine Translationnelle et Neurogénétique, Institut de Génétique et de Biologie Moléculaire et Cellulaire, CNRS/ \\ INSERM/ULP, IIIkirch, France
}

Multiple studies in animal models and humans suggest that the endogenous opioid system is an important neurobiological substrate for nicotine addictive properties. In this study, we evaluated the participation of $\delta$-opioid receptors in different behavioral responses of nicotine by using $\delta$-opioid receptor knockout mice. Acute nicotine administration induced hypolocomotion and antinociception in wildtype mice, which were similar in knockout animals. The development of tolerance to nicotine-induced antinociception was also similar in both genotypes. In agreement, the expression and functional activity of $\delta$-opioid receptors were not modified in the different layers of the spinal cord and brain areas evaluated after chronic nicotine treatment. The somatic manifestation of the nicotine withdrawal syndrome precipitated by mecamylamine was also similar in wild-type and $\delta$-opioid receptor knockout mice. In contrast, nicotine induced a conditioned place preference in wild-type animals that was abolished in knockout mice. Moreover, a lower percentage of acquisition of intravenous nicotine self-administration was observed in mice lacking $\delta$-opioid receptors as well as in wild-type mice treated with the selective $\delta$-opioid receptor antagonist naltrindole. Accordingly, in-vivo microdialysis studies revealed that the enhancement in dopamine extracellular levels induced by nicotine in the nucleus accumbens was reduced in mutant mice. In summary, the present results show that $\delta$-opioid receptors are involved in the modulation of nicotine rewarding effects. However, this opioid receptor does not participate either in several acute effects of nicotine or in the development of tolerance and physical dependence induced by chronic nicotine administration.

Neuropsychopharmacology (2012) 37, 2332-2344; doi: I 0.1038/npp.20 I2.88; published online 6 June 2012

Keywords: dependence; tolerance; reward; knockout; microdialysis; self-administration

\section{INTRODUCTION}

Nicotine is the main psychoactive component of tobacco, which plays a major role in tobacco dependence (Dani and Balfour, 2011). Nicotine produces its pharmacological responses by acting on nicotinic acetylcholine receptors that are mainly located at a presynaptic level. The activation of these receptors by nicotine increases the release of several neurotransmitters, including the endogenous opioid peptides (Hadjiconstantinou and Neff, 2011). Animal studies have provided evidence for distinct roles of the different components of the endogenous opioid system in the addictive properties of nicotine (Berrendero et al, 2010). The activation of $\mu$-opioid receptors (MOR) (Berrendero et al, 2002; Walters et al, 2005; Göktalay et al, 2006; Ismayilova and Shoaib, 2010; Liu and Jernigan, 2011) by

\footnotetext{
* Correspondence: Professor R Maldonado, Department of Experimental and Health Sciences, Laboratory of Neuropharmacology, Universitat Pompeu Fabra, PRBB, C/Doctor Aiguader 88, Barcelona 08003, Spain, Tel: + 3493 3160824, Fax: + 3493 3160901,

E-mail: rafael.maldonado@upf.edu

${ }^{3}$ These authors contributed equally to this work.

Received 8 March 2012; revised 19 April 2012; accepted 2 May 2012
}

their endogenous ligand $\beta$-endorphin (Trigo et al, 2009) is involved in the rewarding effects of nicotine. Endogenous enkephalins, which bind to MOR and $\delta$-opioid receptors (DOR), have also been shown to participate in nicotine reward (Berrendero et al, 2005). In contrast, opioid peptides derived from prodynorphin, which are the main endogenous ligands for $\kappa$-opioid receptors (KOR), seem to participate in nicotine aversive responses since the deletion of the prodynorphin gene improved nicotine self-administration (Galeote et al, 2009). In agreement with these preclinical results, the non-selective opioid antagonist naltrexone has shown efficacy for smoking cessation mainly in female smokers (King et al, 2006), and smokers reporting high rates of depressive symptoms (Walsh et al, 2008).

DOR is highly expressed in the olfactory bulb, cortex, amygdala, caudate-putamen, and nucleus accumbens, while moderate levels of this receptor are reported in the interpeduncular and pontine nuclei, hippocampus, spinal cord, and dorsal root ganglia (Mansour et al, 1987; Goody et al, 2002; Pradhan and Clarke, 2005). This distribution is consistent with the participation of DOR in the control of pain, emotional processing, cognitive function, motivation, and reward (Pradhan et al, 2011). Pharmacological and 
genetic approaches suggest that DOR activity may participate in particular aspects of the addictive properties of some drugs of abuse (Shippenberg et al, 2008). However, the role of DOR in the behavioral responses of nicotine related to its addictive properties has not been yet clarified. Indeed, so far few studies have examined this important topic and their results have not been yet conclusive. The selective DOR antagonist naltrindole increased the anxiogenic-like effects of nicotine (Balerio et al, 2005), while it did not affect its anxiolytic-like responses. Recently, the same DOR antagonist did not significantly modify nicotine intravenous selfadministration in rats (Ismayilova and Shoaib, 2010; Liu and Jernigan, 2011). However, a desensitization of DOR was found in the nucleus accumbens during early nicotine withdrawal in mice (McCarthy et al, 2011), suggesting a possible role for this receptor in the affective component of nicotine abstinence.

The aim of this study was to evaluate the participation of DOR in the behavioral responses of nicotine related to its addictive properties by using DOR knockout mice. Acute effects of nicotine on locomotion, nociception as well as the development of tolerance to nicotine-induced antinociception were evaluated in wild-type and mutant animals. The somatic signs of mecamylamine-precipitated nicotine withdrawal were analyzed in both genotypes. We also investigated nicotine rewarding properties by using the conditioning place preference and the intravenous nicotine self-administration paradigm. A pharmacological approach using the selective DOR antagonist naltrindole was also employed in the self-administration paradigm to confirm the role played by this opioid receptor. In-vivo microdialysis studies were performed to determine the effects of nicotine on the extracellular levels of dopamine in the nucleus accumbens.

\section{MATERIALS AND METHODS}

\section{Animals}

Experiments were performed in male DOR knockout mice and their wild-type C57BL/6J littermates (8- to 12-weekold). Additional C57BL/6J mice were used for autoradiographic studies and self-administration experiments. The generation of mice lacking DOR has been previously described (Filliol et al, 2000). Knockout mice used in the present study were crossed $>10$ generations to $\mathrm{C} 57 \mathrm{Bl} / 6 \mathrm{~J}$ mice. DOR knockout mice were genotyped using the following primers: $5^{\prime}$-AGAACACGCAGCACAAAGACTGG $-3^{\prime}, 5^{\prime}$-ACCGCTTCCTCGTGCTTTACGGTA- $3^{\prime}$ and $5^{\prime}$-GACC ACGTGGTGCGCGCGGC- $3^{\prime}$. The multiplex PCR produces a 1035-bp band for the wild-type allele and a 591-bp band for the knockout allele and both for heterozygous mice. Mice were housed five per cage in a temperature-controlled room $\left(21 \pm 1^{\circ} \mathrm{C}\right)$ with a 12 -h light/dark cycle (lights on between 0800 and 2000 hours). Food and water were available ad libitum. Mice were habituated to their new environment and handled for 1 week before the experimental procedure was started. The same group of wild-type and knockout mice was used in the acute, conditioning place preference and nicotine withdrawal experiments following the ethical guidelines to reduce the number of animals required in the study. Animals were allowed to rest during 10 days between each experimental procedure. Three different and independent groups of animals were used for the tolerance, microdialysis, and intravenous self-administration experiments. Animal procedures were conducted in accordance with the guidelines of the European Communities Directive 86/609/EEC regulating animal research and approved by the local ethical committee (CEA-PRBB). The observer was blind to genotype and treatment in all the experiments.

\section{Drugs}

(-)-Nicotine hydrogen tartrate salt and mecamylamine hydrochloride (Sigma, Madrid, Spain) were dissolved in physiological saline (0.9\%) and administered subcutaneously (s.c.) in a volume of $10 \mathrm{ml} / \mathrm{kg}$ body weight. For the experiments of nicotine withdrawal, nicotine was administered at the dose of $8.77 \mathrm{mg} / \mathrm{kg} /$ day by using subcutaneously implanted osmotic minipumps. For the self-administration studies, the $\mathrm{pH}$ of nicotine solution was adjusted to 7.4 with sodium hydroxide and was contingently administered by intravenous (i.v.) route. All nicotine doses were calculated as nicotine-free base. The DOR antagonist naltrindole (Sigma) was dissolved in physiological saline $(0.9 \%)$ and administered intraperitoneally (i.p.) in a volume of $10 \mathrm{ml} / \mathrm{kg}$ body weight. Ketamine hydrochloride $(100 \mathrm{mg} /$ kg) (Imalgène 1000; Rhône Mérieux, Lyon, France) and xylazine hydrochloride $(20 \mathrm{mg} / \mathrm{kg}$ ) (Sigma) were mixed and dissolved in ethanol (5\%) and distilled water (95\%). This anesthetic mixture was administered i.p. in an injection volume of $10 \mathrm{ml} / \mathrm{kg}$ body weight.

\section{Acute Pharmacological Responses}

The locomotor responses induced by acute nicotine $(0.35$, 1.05 , and $2.10 \mathrm{mg} / \mathrm{kg}$, s.c.) or saline administration were measured by using individual locomotor activity boxes $\left(9 \times 20 \times 11 \mathrm{~cm}^{3}\right.$, Imetronic, Pessac, France), as previously described (Berrendero et al, 2002). The antinociceptive responses were determined after nicotine $(0.35,1.05$, and $2.10 \mathrm{mg} / \mathrm{kg}$, s.c.) or saline administration by using the tailimmersion and hot-plate tests respectively, as previously reported (Simonin et al, 1998). In the tail-immersion test, the water temperature was maintained at $50 \pm 0.5^{\circ} \mathrm{C}$ using a thermo-regulated water circulating pump (Clifton, North Somerset, UK). The time taken to withdraw the tail was determined and a cutoff was set up at $5 \mathrm{~s}$ in order to prevent tissue damage. In the hot-plate test, the heated surface of the plate was kept at $52 \pm 0.1^{\circ} \mathrm{C}$ (Columbus Instruments, Columbus, OH, USA). The nociceptive threshold evaluated was the jumping response. In the absence of jumps, a $240-s$ cutoff was used to prevent tissue damage. The data were expressed as percentage of maximum possible effect using the following equation $(\mathrm{MPE} \%)=($ test latency - control latency)/ (cutoff time - control latency) $\times 100$.

\section{Evaluation of Tolerance to Nicotine-Induced Antinociception}

To assess tolerance, saline or nicotine were chronically administered $(1.75 \mathrm{mg} / \mathrm{kg}$, s.c., three times daily) during 12 days. The antinociceptive responses of nicotine were 
measured on days $1,2,4,6,8,10$, and 12 after starting nicotine treatment by using the tail-immersion test, $15 \mathrm{~min}$ after the first daily injection, as previously reported (Galeote et al, 2006). The water temperature was maintained at $48 \pm 0.5^{\circ} \mathrm{C}$ using a thermo-regulated water circulating pump (Clifton, North Somerset UK). The time to withdraw the tail was determined and a cutoff was set up at $15 \mathrm{~s}$ in order to prevent tissue damage (Galeote et al, 2006).

\section{Autoradiographic Procedures}

Spinal cord and brain slicing. Nicotine tolerant and control mice were sacrificed $1 \mathrm{~h}$ after the last nicotine or saline injection. Their brains and spinal cords were quickly removed and rapidly frozen by immersion in 2-methylbutane surrounded by dry ice. All samples were stored at $-80{ }^{\circ} \mathrm{C}$ during a similar period of time until processed for analyses of DOR binding and activation of GTP-binding proteins. The brain coronal and lumbar spinal cord sections were cut in a cryostat $(20 \mu \mathrm{m}$ thick), thaw-mounted on gelatin/chrome-coated slides, dried briefly at $30^{\circ} \mathrm{C}$ and stored at $-80^{\circ} \mathrm{C}$ until used. The brain structures were identified using the mouse brain atlas of Paxinos and Franklin (1997), and spinal cord structures were referenced to cytoarchitecture of spinal cord of rats (Molander et al, 1984).

Autoradiography of DOR binding. The autoradiographic procedure was performed as detailed previously (Kitchen et al, 1997). See Supplementary Materials and Methods for further details.

DPDPE-stimulated $\left[{ }^{35} S\right] G T P \gamma S$-binding autoradiography. The protocol used was performed as previously detailed (Sim et al, 1995). See Supplementary Materials and Methods for further details.

\section{Nicotine Dependence and Withdrawal}

Nicotine dependence was induced by using Alzet osmotic minipumps (Model 2001; Alzet, Cupertino, CA, USA), as previously reported (Castañé et al, 2002). These minipumps, implanted subcutaneously under brief ether anesthesia, contained saline or nicotine solutions and delivered a constant s.c. flow in a rate of $1 \mu \mathrm{l} / \mathrm{h}$. Mice received a mean dose of $\sim 8.77 \mathrm{mg} / \mathrm{kg} / \mathrm{day}$ of nicotine during 6 days. Nicotine withdrawal was precipitated 6 days after minipump implantation by injection of the nicotinic receptor antagonist mecamylamine $(1 \mathrm{mg} / \mathrm{kg}$, s.c.). Nicotine dose used in this study to develop physical dependence was chosen based on the results obtained in previous studies (Berrendero et al, 2005). The somatic signs of withdrawal were evaluated $10 \mathrm{~min}$ before and immediately after mecamylamine injection during a period of $30 \mathrm{~min}$, as previously reported (Castañé et al, 2002). The number of wet dog shakes, front paw tremors, sniffing, and scratches was counted. Body tremor, ptosis, teeth chattering, genital licks, and piloerection were scored 1 for appearance or 0 for non-appearance within each $5 \mathrm{~min}$ time. The locomotor activity over 5 -min periods was rated 0,1 , or 2 ( 0 for inactivity, 1 for low activity, and 2 for normal activity). A global withdrawal score was calculated for each animal by giving each individual sign a relative weight: 0.5 for each episode of wet dog shake, front paw tremor, sniffing, and scratching; and 1 for the presence of body tremor, ptosis, teeth chattering, genital lick, and piloerection during each observation period of $5 \mathrm{~min}$. The relative weight of locomotor activity for each $5 \mathrm{~min}$ period was 0 for normal activity, 0.5 for low activity, and 1 for inactivity.

\section{Place-Conditioning Paradigm}

The conditioned place preference to nicotine was evaluated using a non-biased procedure, as previously reported (Castañé et al, 2002). The apparatus consisted of two main square conditioning compartments separated by a triangular central division. During the preconditioning phase, each mouse was placed in the middle of the central division and had free access to both compartments of the conditioning apparatus for $18 \mathrm{~min}$, with the time spent in each compartment recorded. During the conditioning phase, mice were treated during 8 days with alternate injections of nicotine $(0.17 \mathrm{mg} / \mathrm{kg}$, s.c. $)$ or saline. Mice were confined into the corresponding compartment immediately after injection by using guillotine doors matching the walls for $20 \mathrm{~min}$. The postconditioning phase was conducted as in the preconditioning phase (ie, free access to both compartments for $18 \mathrm{~min}$ ) and the time spent in each compartment was recorded. The time in the central area was proportionally shared and added to the time value of each compartment, as previously reported (Maldonado et al, 1997). The data were expressed as the time spent in the drug-paired compartment during preconditioning and test phases.

\section{Intravenous Nicotine Self-Administration}

Apparatus. The experiments were conducted in mouse operant chambers (Model ENV-307A-CT; Med Associates, Georgia, VT, USA) equipped with two holes, one randomly selected as the active hole and the other as the inactive hole. Pump noise and stimuli lights (cues), one located inside the active hole and the other above it were paired with the delivery of the reinforcer. Nicotine ( 15 and $30 \mu \mathrm{g} / \mathrm{kg} /$ infusion) was delivered in a volume of $23.5 \mu \mathrm{l}$ over $2 \mathrm{~s}$ via a syringe that was mounted on a microinfusion pump and connected via Tygon tubing to a single channel liquid swivel and to the mouse intravenous catheter. Independent groups of wild-type and knockout animals were used for each nicotine dose.

Jugular vein catheterization. Mice were anesthetized with a ketamine/xylazine mixture and then implanted with indwelling i.v. silastic catheters on their right jugular vein as previously described (Soria et al, 2005). After surgery, animals were allowed to recover for 3 days before initiation of self-administration sessions.

Nicotine self-administration procedure. The experiments were conducted using the operant model recently described (Martín-García et al, 2009) with slight modifications. Genetic (DOR knockout mice) and pharmacological (naltrindole administration) approaches were used in this set of experiments. For the genetic approach, the responses of DOR knockout mice and wild-type littermates were compared during the different nicotine self-administration sessions $(15-30 \mu \mathrm{g} / \mathrm{kg} /$ infusion). For the pharmacological 
studies, mice received an injection of naltrindole (2.5 and $5 \mathrm{mg} / \mathrm{kg}$, i.p.) or saline $30 \mathrm{~min}$ before each daily session of nicotine self-administration ( $30 \mu \mathrm{g} / \mathrm{kg} /$ infusion). The doses of naltrindole in the present study are currently used to selectively block different behavioral responses mediated by the activation of DOR (Ciccocioppo et al, 2002; Brüning et al, 2010). In all, $1 \mathrm{~h}$ daily self-administration sessions were conducted consecutively for 10 days. Mice were trained under a fixed ratio 1 schedule of reinforcement with a 10-s time-out. Each daily session started with a priming injection of the drug. The stimuli light together with the pump noise signaled delivery of nicotine infusion. During the 10-s time-out period, the cue light was off and no reward was provided after nose-poking on the active hole. Responses on the inactive hole and all the responses elicited during the 10-s time-out period were also recorded. The session was terminated after 50 reinforcers were delivered or after $1 \mathrm{~h}$, whichever occurred first. The criteria for the acquisition of self-administration behavior were achieved when in three consecutive sessions: (1) mice maintained a stable responding with $<20 \%$ deviation from the mean of the total number of reinforcers earned $(80 \%$ stability); (2) at least $75 \%$ responding on the active hole; and (3) a minimum of six reinforcers per session. Subsequently, mice were changed to a progressive ratio schedule of reinforcement on day 11, in which the response requirement to earn an infusion escalated according to the following series: 1-2-3-5-12-18-27-40-60-90-135-200-300450-675-1000. The patency of intravenous catheters was evaluated at the end of nicotine self-administration training by an infusion of $0.05-0.10 \mathrm{ml}$ of thiopental sodium through the catheter. If prominent signs of anesthesia were not apparent within $3 \mathrm{~s}$ of the infusion, the mouse was removed from the experiment. Data from acquisition of nicotine self-administration were expressed as number of infusions and as area under the curve (AUC). AUC was calculated by using a standard trapezoid method, AUC $=\left[0.5 \times\left(B_{1}+\right.\right.$ $\left.\left.B_{2}\right) \times h\right]+\left[0.5 \times\left(B_{2}+B_{3}\right) \times h\right]+\ldots\left[0.5 \times\left(B_{n}+B_{n+1}\right)\right.$ $\times h$, where $B_{n}$ were the infusions received for each mouse and $h$ was the time (days) passed between the consecutive measurements (Gibaldi and Perrier, 1975).

\section{Microdialysis Procedure}

The evaluation of the extracellular dopamine levels in the nucleus accumbens was performed as previously reported (Berrendero et al, 2005). See Supplementary Materials and Methods for further details.

\section{Statistical Analysis}

Acute nicotine effects, global withdrawal scores, and AUC of microdialysis data were compared by using a betweensubjects two-way ANOVA (genotype and treatment as factors of variation), followed by post hoc comparisons (Fisher LSD test) when required. For place-conditioning studies, time spent in the drug-paired compartment during pretest phase was compared in the different groups by oneway ANOVA to ensure the use of an unbiased procedure. Individual comparisons of time spent in the drug-paired compartment during preconditioning and postconditioning phases were made with a paired two-tailed Student's $t$-test.
The microdialysis and antinociceptive tolerance data were analyzed using three-way ANOVA with treatment (saline and nicotine) and genotype (wild-type and knockout) as between-subjects factors and time after nicotine injection (microdialysis) or day (tolerance) as within-subjects factor. To analyze the acquisition of nicotine self-administration, the number of infusions reached during the training period were compared using three-way ANOVA with repeated measures with genotype or treatment and hole as betweensubject factors and day as within-subject factor. AUC values obtained in the self-administration paradigm were compared using two-way ANOVA with hole and genotype or treatment as factor of variations, followed by post hoc comparisons (Fisher LSD test) when required. The $\chi^{2}$ analysis was used to compare between genotypes or treatments the percentage of mice that acquired self-administration criteria. Biochemical studies were analyzed by using two-way ANOVA with repeated measures (treatment as between-subjects factor and brain region or spinal cord layer as within-subjects factor), followed by Fisher LSD test when appropriate. The level of significance was $p<0.05$ in all experiments.

\section{RESULTS}

\section{Nicotine Similarly Decreased Locomotion in Wild-Type and DOR-Deficient Mice}

On days 1,2, and 3, mice were exposed to the locomotor activity boxes in order to be habituated to the test environment, and acute effects of nicotine were evaluated on day 4. During habituation, knockout mice showed significantly higher locomotion than wild-type (data not shown), as previously reported (Filliol et al, 2000). Nicotine (0.35, 1.05, and $2.10 \mathrm{mg} / \mathrm{kg}$, s.c.) decreased locomotion similarly in wildtype and DOR knockout mice (Figure 1a and b). Thus, twoway ANOVA for horizontal activity revealed a significant effect of treatment $\left(\mathrm{F}_{(3,75)}=77.47, p<0.01\right)$, but no genotype effect $\left(\mathrm{F}_{(1,75)}=2.91\right.$, n.s.), nor interaction between treatment and genotype $\left(\mathrm{F}_{(3,75)}=0.71\right.$, n.s.). Nicotine $(0.35,1.05$, and $2.10 \mathrm{mg} / \mathrm{kg})$ significantly decreased horizontal activity $(p<0.01)$ in both genotypes (Figure 1a). Two-way ANOVA for vertical activity also revealed a significant effect of treatment $\left(\mathrm{F}_{(3,75)}=59.33, p<0.01\right)$, but no genotype effect $\left(\mathrm{F}_{(1.75)}=1.49\right.$, n.s. $)$, nor interaction between these two factors $\left(\mathrm{F}_{(3,75)}=0.65\right.$, n.s. $)$. Nicotine $(0.35,1.05$, and $2.10 \mathrm{mg} / \mathrm{kg})$ also significantly decreased vertical activity $(p<0.01)$ in both genotypes (Figure $1 b$ ).

\section{Nicotine-Induced Antinociception Was Similar in Wild-Type and DOR-Deficient Mice}

Nicotine-induced antinociception $(0.35,1.05$, and $2.10 \mathrm{mg} /$ $\mathrm{kg}$, s.c.) was similar in wild-type and knockout mice (Figure $1 \mathrm{c}$ and $\mathrm{d}$ ). In the tail-immersion test, two-way ANOVA revealed a significant effect of treatment $\left(\mathrm{F}_{(3,80)}=7.21\right.$, $p<0.01)$, but not effect of genotype $\left(\mathrm{F}_{(1,80)}=0.76\right.$, n.s. $)$, nor interaction between these two factors $\left(\mathrm{F}_{(3,80)}=1.38\right.$, n.s. $)$. Nicotine antinociceptive responses at the doses of 1.05 and $2.10 \mathrm{mg} / \mathrm{kg}$ were similar in both genotypes $(p<0.01)$ (Figure 1c). In the hot-plate test, two-way ANOVA revealed a significant effect of treatment $\left(\mathrm{F}_{(3,80)}=28.01, p<0.05\right)$, but not effect of genotype $\left(\mathrm{F}_{(1,80)}=0.37\right.$, n.s.), nor interaction 

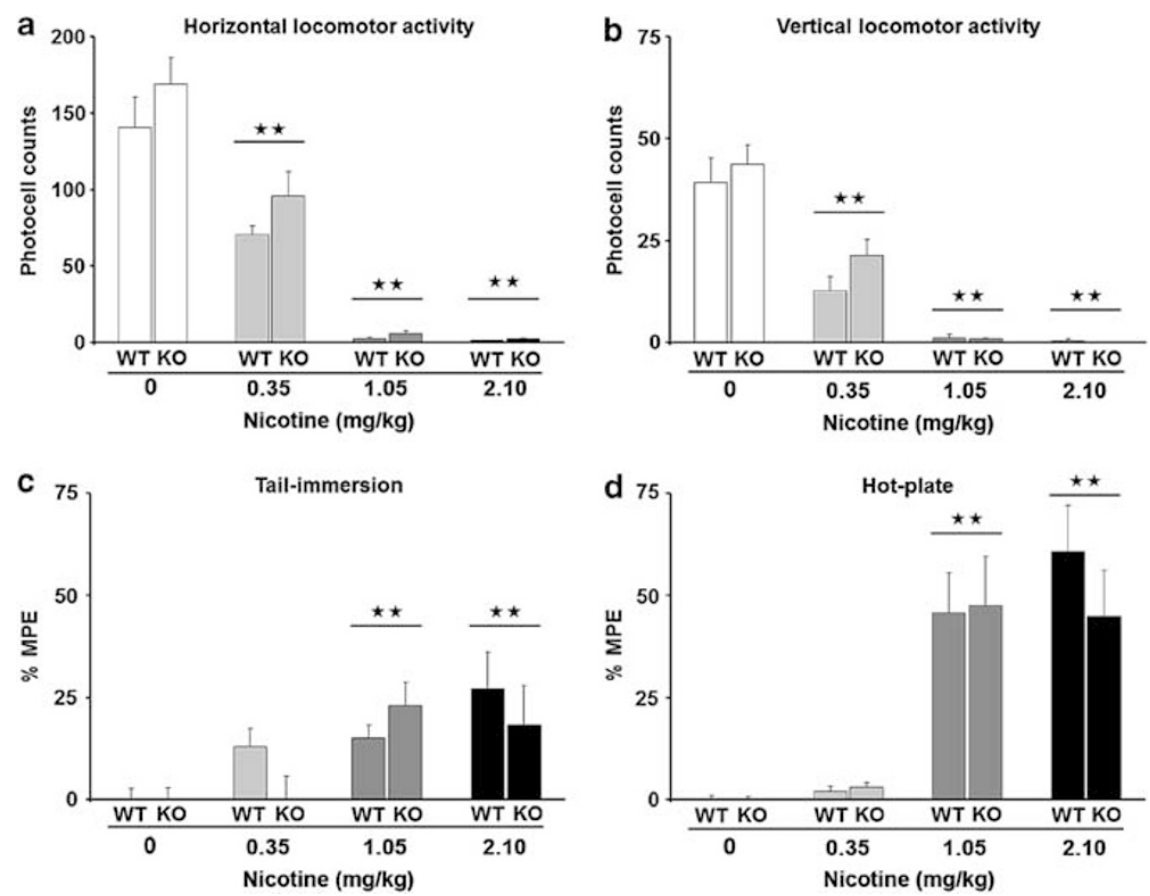

Figure I Effects of acute nicotine (0, 0.35, I.05, and $2.10 \mathrm{mg} / \mathrm{kg}$, s.c.) on locomotion and antinociception in wild-type and DOR knockout mice. Horizontal (a) and vertical locomotion (b) were measured during a 10 -min period 5 min after nicotine administration, whereas antinociceptive responses in the tailimmersion (c) and the hot-plate test (d) were evaluated 15 and 16 min, respectively, following nicotine treatment. Data are expressed as mean \pm SEM of photocell counts for locomotion and percentage of maximum possible effect (MPE) for antinociception experiments. $* p<0.05$, ** $p<0.0$ I compared with the control group (Fisher LSD test) ( $n=9-12$ mice per group).

between both factors $\left(\mathrm{F}_{(3,80)}=0.58\right.$, n.s.). Nicotine antinociceptive responses at the doses of 1.05 and $2.10 \mathrm{mg} / \mathrm{kg}$ $(p<0.01)$ were similar in both genotypes (Figure 1d).

The Development of Tolerance to Nicotine Antinociceptive Effects Was Similar in Wild-Type and DOR Knockout Mice

Chronic nicotine treatment $(1.75 \mathrm{mg} / \mathrm{kg}$, s.c., three times daily during 12 days) developed similar antinociceptive tolerance in wild-type and DOR knockout mice. Three-way ANOVA revealed a significant effect of day $\left(\mathrm{F}_{(6,210)}=31.67\right.$, $p<0.01)$, treatment $\left(\mathrm{F}_{(1,35)}=9.35, p<0.01\right)$, but not genotype effect $\left(\mathrm{F}_{(1,35)}=2.51\right.$, n.s.). Three-way interaction between factors was not significant, and the only two-way significant interaction was revealed between day and treatment $\left(\mathrm{F}_{(6,210)}=11.84, p<0.01\right)$ (Figure 2$)$.

\section{The Density of DOR Was not Modified in the Spinal} Cord and Brain in Nicotine Tolerant Mice

The density of DOR in the different layers of the spinal cord and brain areas evaluated was not modified in nicotine tolerant mice (Table 1). Thus, two-way ANOVA revealed a significant brain area effect $\left(\mathrm{F}_{(6,60)}=81.76, p<0.01\right)$, but no effect of treatment $\left(\mathrm{F}_{(1,10)}=0.48\right.$, n.s.), nor interaction between both factors $\left(\mathrm{F}_{(6,60)}=1.93\right.$, n.s.). In spinal cord, two-way ANOVA revealed a significant effect of the layer $\left(\mathrm{F}_{(2,18)}=10.46, p<0.01\right)$, but no effect of treatment $\left(\mathrm{F}_{(1,9)}=3.09\right.$, n.s. $)$, nor interaction between both factors $\left(\mathrm{F}_{(2,18)}=0.44\right.$, n.s. $)$.

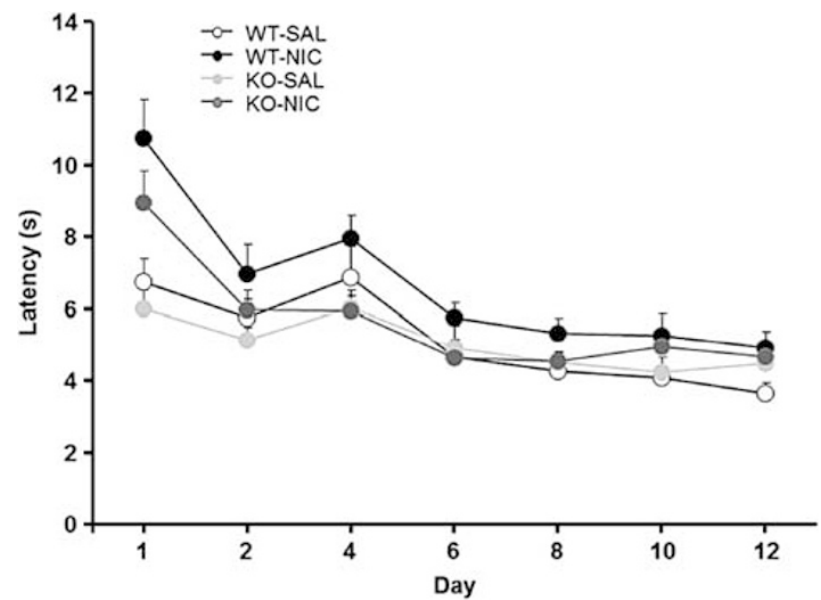

Figure 2 Effects of chronic nicotine administration on nociceptive responses in wild-type and DOR knockout mice. Tolerance to the antinociceptive effects induced by nicotine was observed in the tailimmersion test. Mice received repeated nicotine administration ( $1.75 \mathrm{mg} / \mathrm{kg}$, s.c., three times a day for 12 days) and nociceptive threshold was evaluated 15 min after morning nicotine injection on days I, 2, 4, 6, 8, 10 , and 12. Results are expressed as mean \pm SEM of latency time in saline and nicotine-treated mice ( $n=9-10$ mice for each group).

\section{DPDPE-Stimulated $\left[{ }^{35} \mathrm{~S}\right] \mathrm{GTP} \gamma \mathrm{S}$-Binding Autoradiography in Spinal Cord and Brain Was not Modified in Nicotine Tolerant Mice}

The activation of G-proteins by DOR stimulation was similar in the different layers of the spinal cord and brain areas evaluated in wild-type mice chronically treated with 
Table I $\delta$-Opioid Receptor Binding (fmol/mg tissue) in Several Spinal Cord and Brain Regions of Saline or Chronic NicotineTreated Mice

\begin{tabular}{|c|c|c|c|}
\hline & $\begin{array}{l}\text { Saline chronic } \\
\text { treatment }\end{array}$ & $\begin{array}{l}\text { Nicotine chronic } \\
\text { treatment }\end{array}$ & $\begin{array}{l}\text { One-way } \\
\text { ANOVA }\end{array}$ \\
\hline \multicolumn{4}{|l|}{ Spinal cord } \\
\hline $\begin{array}{l}\text { Superficial layers } \\
\text { (I and II) }\end{array}$ & $32.34 \pm 1.29$ & $28.76 \pm 1.68$ & NS \\
\hline Layers III-VI & $28.83 \pm 1.55$ & $23.68 \pm 1.04$ & NS \\
\hline Layer X & $31.76 \pm 2.47$ & $28.39 \pm 1.75$ & NS \\
\hline \multicolumn{4}{|l|}{ Brain } \\
\hline $\begin{array}{l}\text { Lateral caudate } \\
\text { putamen }\end{array}$ & $146 \pm 9.80$ & $160.59 \pm 7.25$ & NS \\
\hline $\begin{array}{l}\text { Medial caudate } \\
\text { putamen }\end{array}$ & $92.27 \pm 7.76$ & $\mid 08.01 \pm 7.28$ & NS \\
\hline $\begin{array}{l}\text { Nucleus } \\
\text { accumbens }\end{array}$ & $61.32 \pm 7.11$ & $70.34 \pm 7.19$ & NS \\
\hline $\begin{array}{l}\text { Olfactory } \\
\text { tubercle }\end{array}$ & $79.98 \pm 10.74$ & $97.91 \pm 15.45$ & NS \\
\hline Cortex & $64.79 \pm 7.32$ & $73.85 \pm 7.58$ & NS \\
\hline Amygdala & $73.24 \pm 9.20$ & $57.92 \pm 6.04$ & NS \\
\hline Hippocampus & $36.73 \pm 6.69$ & $38.71 \pm 8.53$ & NS \\
\hline
\end{tabular}

Values are expressed as mean \pm SEM of 5-6 animals per group.

Table 2 DPDPE-Stimulated $\left[{ }^{35} \mathrm{~S}\right]$ GTP $\gamma S$ Binding (\% of Stimulation of Basal Binding) in Several Spinal Cord and Brain Regions of Saline or Chronic Nicotine-Treated Mice

\begin{tabular}{|c|c|c|c|}
\hline & $\begin{array}{l}\text { Saline chronic } \\
\text { treatment }\end{array}$ & $\begin{array}{c}\text { Nicotine chronic } \\
\text { treatment }\end{array}$ & $\begin{array}{l}\text { One-way } \\
\text { ANOVA }\end{array}$ \\
\hline \multicolumn{4}{|l|}{ Spinal cord } \\
\hline $\begin{array}{l}\text { Superficial layers } \\
\text { (I and II) }\end{array}$ & $6.80 \pm 1.90$ & $9.09 \pm 3.15$ & NS \\
\hline Layers III-VI & $6.72 \pm 2.84$ & $5.43 \pm 2.45$ & NS \\
\hline Layer X & $6.73 \pm 1.75$ & $8.86 \pm 3.64$ & NS \\
\hline \multicolumn{4}{|l|}{ Brain } \\
\hline $\begin{array}{l}\text { Lateral caudate } \\
\text { putamen }\end{array}$ & $27.60 \pm 10.03$ & $24.33 \pm 8.63$ & NS \\
\hline $\begin{array}{l}\text { Medial caudate } \\
\text { putamen }\end{array}$ & $25.69 \pm 9.31$ & $24.54 \pm 9.56$ & NS \\
\hline $\begin{array}{l}\text { Nucleus } \\
\text { accumbens }\end{array}$ & $|9.86 \pm| 0.6 \mid$ & $26.49 \pm 14.17$ & NS \\
\hline Cortex & $12.78 \pm 6.96$ & $12.74 \pm 6.47$ & NS \\
\hline Amygdala & $37.59 \pm 11.00$ & $30.13 \pm 12.54$ & NS \\
\hline Hippocampus & $28.83 \pm 4.53$ & $25.45 \pm 8.81$ & NS \\
\hline Hypothalamus & $28.83 \pm 10.45$ & $20.03 \pm 9.31$ & NS \\
\hline
\end{tabular}

Values are expressed as mean \pm SEM of 4-6 animals per group.

nicotine or saline. Thus, two-way ANOVA showed no significant effect of treatment $\left(\mathrm{F}_{(1,8)}=0.06\right.$, n.s. $)$, brain area $\left(\mathrm{F}_{(6,48)}=1.38\right.$, n.s.), nor interaction between both factors $\left(F_{(6,48)}=0.22\right.$, n.s.). Similarly, two-way ANOVA revealed no significant effect of treatment $\left(\mathrm{F}_{(1,8)}=0.54\right.$, n.s. $)$, layer of the spinal cord $\left(\mathrm{F}_{(2,16)}=5.29\right.$, n.s. $)$, nor interaction between both factors $\left(\mathrm{F}_{(2,16)}=5.07\right.$, n.s.) (Table 2).

\section{Somatic Expression of Nicotine Withdrawal Was Similar in Wild-Type and DOR Knockout Mice}

During the behavioral observation performed before mecamylamine administration, no somatic signs of withdrawal were observed in any experimental group. After mecamylamine injection, nicotine withdrawal syndrome was manifested by the presence of a variety of somatic signs in mice receiving chronic nicotine perfusion, as previously reported (Castañé et al, 2002). The severity of nicotine withdrawal was not modified by the deletion of DOR (Figure 3). Thus, twoway ANOVA calculated for representative somatic signs of withdrawal such as body tremor, paw tremor, and ptosis indicated a significant effect of nicotine treatment $\left(\mathrm{F}_{(1,56)}=33.33, \quad p<0.01 ; \mathrm{F}_{(1,56)}=11.57, \quad p<0.01 ; \mathrm{F}_{(1,56)}=\right.$ 18.23, $p<0.01$, respectively), but no genotype effect $\left(\mathrm{F}_{(1,56)}=0.26\right.$, n.s.; $\mathrm{F}_{(1,56)}=0.07$, n.s.; $\mathrm{F}_{(1,56)}=0.18$, n.s., respectively), nor interaction between treatment and genotype $\left(\mathrm{F}_{(1,56)}=0.26\right.$, n.s.; $\mathrm{F}_{(1,56)}=0.01$, n.s.; $\mathrm{F}_{(1,56)}=0.32$, n.s., respectively). The significant effect of nicotine treatment on body tremor $(p<0.01)$, paw tremor $(p<0.05)$ and ptosis $(p<0.01)$ was similar in both genotypes (Figure $3 a)$. In agreement, two-way ANOVA for the global withdrawal score showed a significant effect of nicotine treatment $\left(\mathrm{F}_{(1,56)}=\right.$ $19.23, p<0.01)$, but no effect of genotype $\left(\mathrm{F}_{(1,56)}=2.70\right.$, n.s. $)$, nor interaction between these factors $\left(\mathrm{F}_{(1,56)}=0.28\right.$, n.s. $)$. The significant effect of nicotine treatment on the global withdrawal score $(p<0.01)$ was similar in both genotypes (Figure 3b).

\section{Nicotine Did not Produce Rewarding Effects in the Place Preference Paradigm in DOR Knockout Mice}

One-way ANOVA revealed a similar time spent in the drug-paired compartment during the preconditioning phase in the different groups $\left(\mathrm{F}_{(3,56)}=0.36\right.$, n.s. $)$, ensuring the use of an unbiased procedure (Figure 4). A significant rewarding effect of nicotine was observed in the placeconditioning paradigm in wild-type, but not in knockout mice. Thus, wild-type animals conditioned with the dose of nicotine that had revealed reliable rewarding effects in this paradigm in our experimental conditions $(0.17 \mathrm{mg} / \mathrm{kg}$, s.c.) (Castañé et al, 2002; Berrendero et al, 2005) spent significantly $(p<0.05)$ more time in the drug-paired compartment during the testing phase than during the preconditioning phase. In contrast, knockout mice receiving this dose of nicotine spent the same time in the drug-paired compartment during both phases (Figure 4).

\section{Nicotine Intravenous Self-Administration Was Impaired in DOR Knockout Mice}

The operant intravenous self-administration paradigm was used to evaluate the influence of the deletion of DOR in the reinforcing properties of nicotine. Different groups of wildtype and DOR knockout mice were trained to selfadminister nicotine at two doses (15 and $30 \mu \mathrm{g} / \mathrm{kg}$ per infusion) during 10 consecutive days. We have previously 

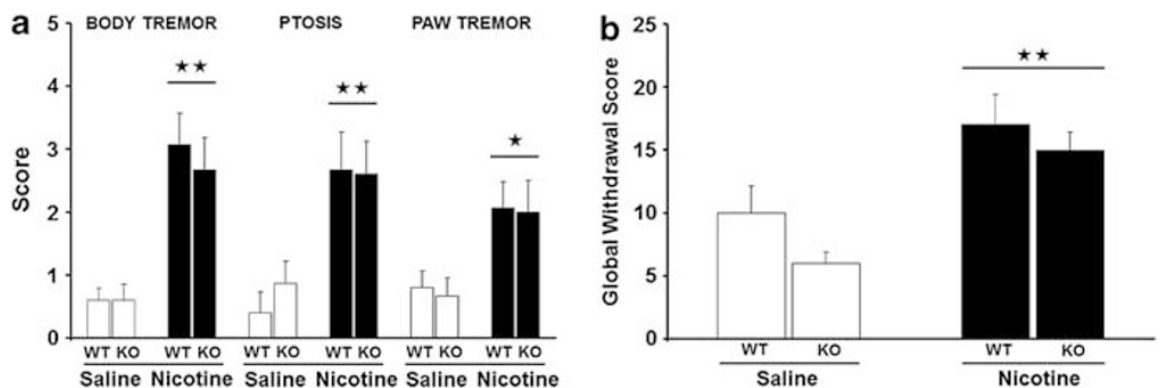

Figure 3 Somatic nicotine withdrawal in wild-type and DOR knockout mice. Acute mecamylamine (I mg/kg, s.c.) was administered to precipitate nicotine withdrawal in wild-type and DOR knockout mice after 6 days of nicotine perfusion $(8.77 \mathrm{mg} / \mathrm{kg} / \mathrm{day})$ from subcutaneously implanted osmotic minipumps. Relevant signs of mecamylamine-precipitated nicotine withdrawal (body tremor, ptosis, paw tremor) (a) and global withdrawal score (b) in wild-type and mutant mice. Data are expressed as mean \pm SEM ( $n=15$ mice per group). $* p<0.05$, $* * p<0.0$ l compared with the control group (Fisher LSD test).

shown using this operant paradigm that mice acquired a reliable operant behavior maintained by nicotine, but not by a control solution such as saline (Martín-García et al, 2009; Plaza-Zabala et al, 2010), under a fixed ratio 1 schedule of reinforcement. A decrease in the percentage of acquisition of nicotine self-administration was observed in knockout mice at the two doses tested. Thus, the percentage of mice that achieved the acquisition criteria for nicotine self-administration at the dose of $15 \mu \mathrm{g} / \mathrm{kg}$ was $70 \%$ for wild-type and $29 \%$ for knockout mice $\left(\chi^{2}=5.72, p<0.05\right)$. Similarly, the percentage of acquisition at the dose of $30 \mu \mathrm{g} / \mathrm{kg}$ was $66 \%$ for wild-type and $33 \%$ for knockout mice $\left(\chi^{2}=4.50, \quad p<0.05\right)$. Three-way ANOVA with repeated measures revealed a significant interaction between the factors hole, day, and genotype in mice trained at the nicotine dose of $15 \mu \mathrm{g} / \mathrm{kg} \quad\left(\mathrm{F}_{(9,135)}=2.19, p<0.05\right)$ (Figure $5 \mathrm{a}$ ) or $30 \mu \mathrm{g} / \mathrm{kg}\left(\mathrm{F}_{(9,144)}=3.50, p<0.01\right)$ (Figure $5 \mathrm{c}$ ). Subsequent post hoc analysis for each day of training revealed lower percentage of active responding for DOR knockout than wild-type mice during the acquisition of nicotine self-administration (Figure $5 \mathrm{a}$ and $\mathrm{c}$ ). Thus, mutant mice displayed an intermittent discrimination pattern at the dose of $15 \mu \mathrm{g} / \mathrm{kg}$ (days 3, 5, 6, 8, and 10) while only discriminated on day 3 at the dose of $30 \mu \mathrm{g} / \mathrm{kg}$. Conversely, wild-type mice showed a reliable and significant discrimination between the active and the inactive hole from the third day of training at the dose of 15 (Figure 5a), and from the second day (with the exception of day 3 ) at the dose of 30 (Figure 5c). In agreement, the total number of infusions earned during the acquisition period expressed by the AUC was lower in DOR knockout than in wild-type mice at the dose of $30 \mu \mathrm{g} / \mathrm{kg}$ (Figure 5d). Thus, two-way ANOVA revealed a significant effect of genotype $\left(\mathrm{F}_{(1,16)}=6.481\right.$, $p<0.05)$ for this dose of nicotine. The decreased acquisition, percentage of active responding, and number of nicotine infusions in DOR knockout mice reveal an impairment in the performance of operant nicotine selfadministration behavior. The maximum effort to obtain a nicotine infusion $(30 \mu \mathrm{g} / \mathrm{kg})$ was evaluated under a progressive ratio schedule. The breaking-point values for DOR knockout mice were significantly lower when compared with wild-type at this nicotine dose $(p<0.05)$ (Figure 5e). The breaking-point values were not analyzed for the dose of $15 \mu \mathrm{g} / \mathrm{kg}$ since no significant differences in the number of infusions (AUC values) were observed between genotypes at this dose of nicotine.

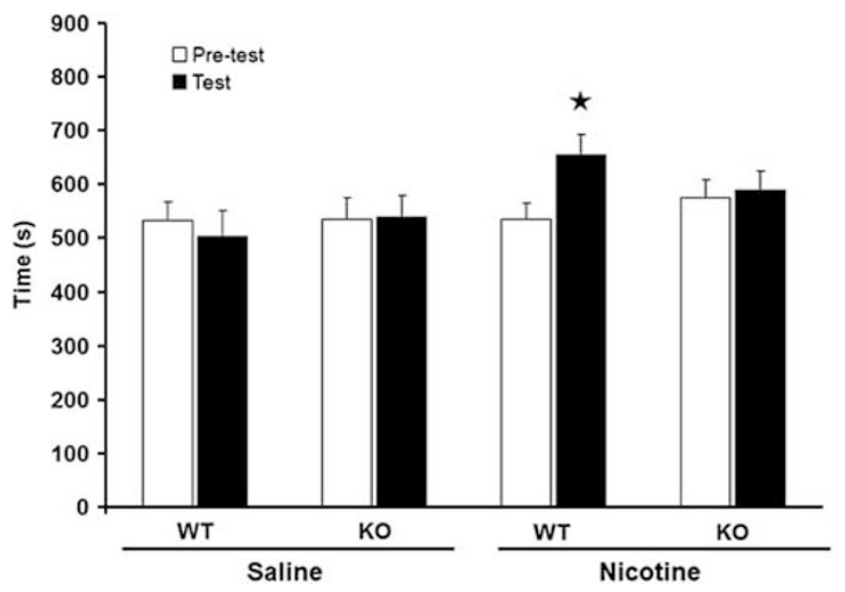

Figure 4 Rewarding effects of nicotine in wild-type and DOR knockout mice in the conditioning place-conditioning paradigm. Four pairings were carried out with nicotine $(0.17 \mathrm{mg} / \mathrm{kg}$, s.c.) or saline on alternate days (see Materials and methods section). Data are expressed as mean \pm SEM of time spent in the drug-paired compartment during preconditioning and test phases. * $p<0.05$ comparison between time spent in each compartment (paired two-tailed Student's t-test) ( $n=15$ mice per group).

\section{The Selective DOR Antagonist Naltrindole Dose- Dependently Impaired Nicotine Intravenous Self- administration}

The participation of DOR in the reinforcing properties of nicotine was further evaluated using the selective DOR antagonist, naltrindole. Three different groups of mice were trained to self-administer nicotine at the dose of $30 \mu \mathrm{g} / \mathrm{kg}$ per infusion and received an i.p. injection of saline (control), $2.5 \mathrm{mg} / \mathrm{kg}$ of naltrindole, or $5 \mathrm{mg} / \mathrm{kg}$ of naltrindole $30 \mathrm{~min}$ before each daily self-administration session. Naltrindole dose-dependently reduced the percentage of acquisition of nicotine self-administration. Thus, while $62.5 \%$ of mice receiving saline achieved the acquisition criteria, only $33.3 \%$ of mice treated with $2.5 \mathrm{mg} / \mathrm{kg}$ of naltrindole $\left(\chi^{2}=3.26, p=0.07\right)$ and $10 \%$ of mice receiving $5 \mathrm{mg} / \mathrm{kg}$ of naltrindole $\left(\chi^{2}=11.76, p<0.01\right)$ acquired the behavior. Three-way ANOVA with repeated measures revealed significant interactions between hole and day $\left(\mathrm{F}_{(9,216)}=5.66, p<0.01\right)$ as well as between hole and treatment $\quad\left(\mathrm{F}_{(2,24)}=3.91, p<0.05\right) \quad$ (Figure 6a). Subsequent post hoc analysis for each day of training revealed 

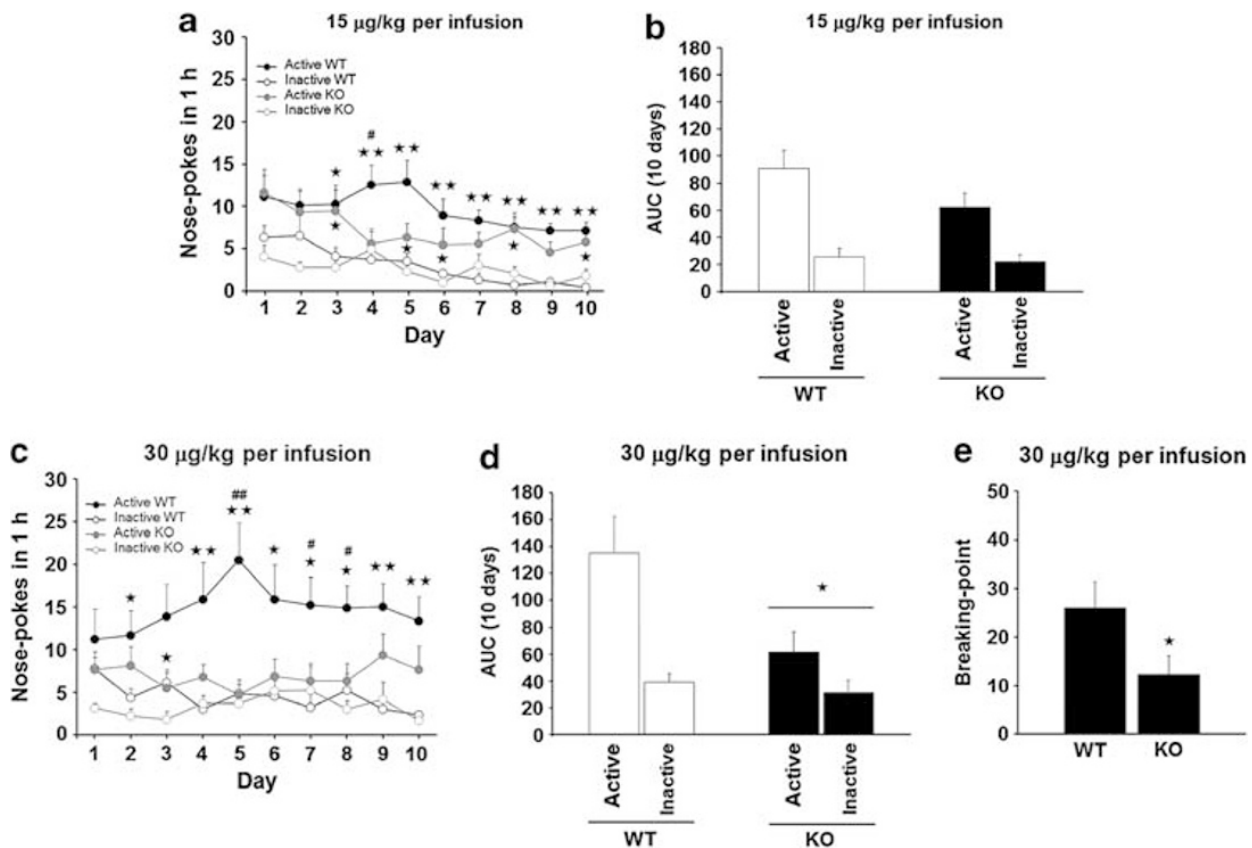

Figure 5 Acquisition of intravenous nicotine self-administration in wild-type ( $15 \mu \mathrm{g} / \mathrm{kg}$ per infusion, $n=10 ; 30 \mu g / \mathrm{kg}$ per infusion, $n=9)$ and DOR knockout mice ( $15 \mu \mathrm{g} / \mathrm{kg}$ per infusion, $n=7 ; 30 \mu \mathrm{g} / \mathrm{kg}$ per infusion, $n=9)$ (a, c) Area under de curve (AUC) values for the number of infusions during the I0 training sessions in wild-type and DOR knockout mice $(b, d)$. Breaking-point values achieved in progressive ratio schedule in wild-type and DOR knockout mice at the dose of $30 \mu \mathrm{g} / \mathrm{kg}$ per infusion (e). Data are expressed as mean \pm SEM. ${ }^{*} p<0.05,{ }^{* *} p<0.01$ comparison between holes, ${ }^{\#} p<0.05,{ }^{\# \#} p<0.0$ I comparison between genotypes in the active hole $(\mathrm{a}, \mathrm{c})$; * $p<0.05$ comparison between genotypes ( $\mathrm{d}, \mathrm{e})$ (Fisher LSD test).
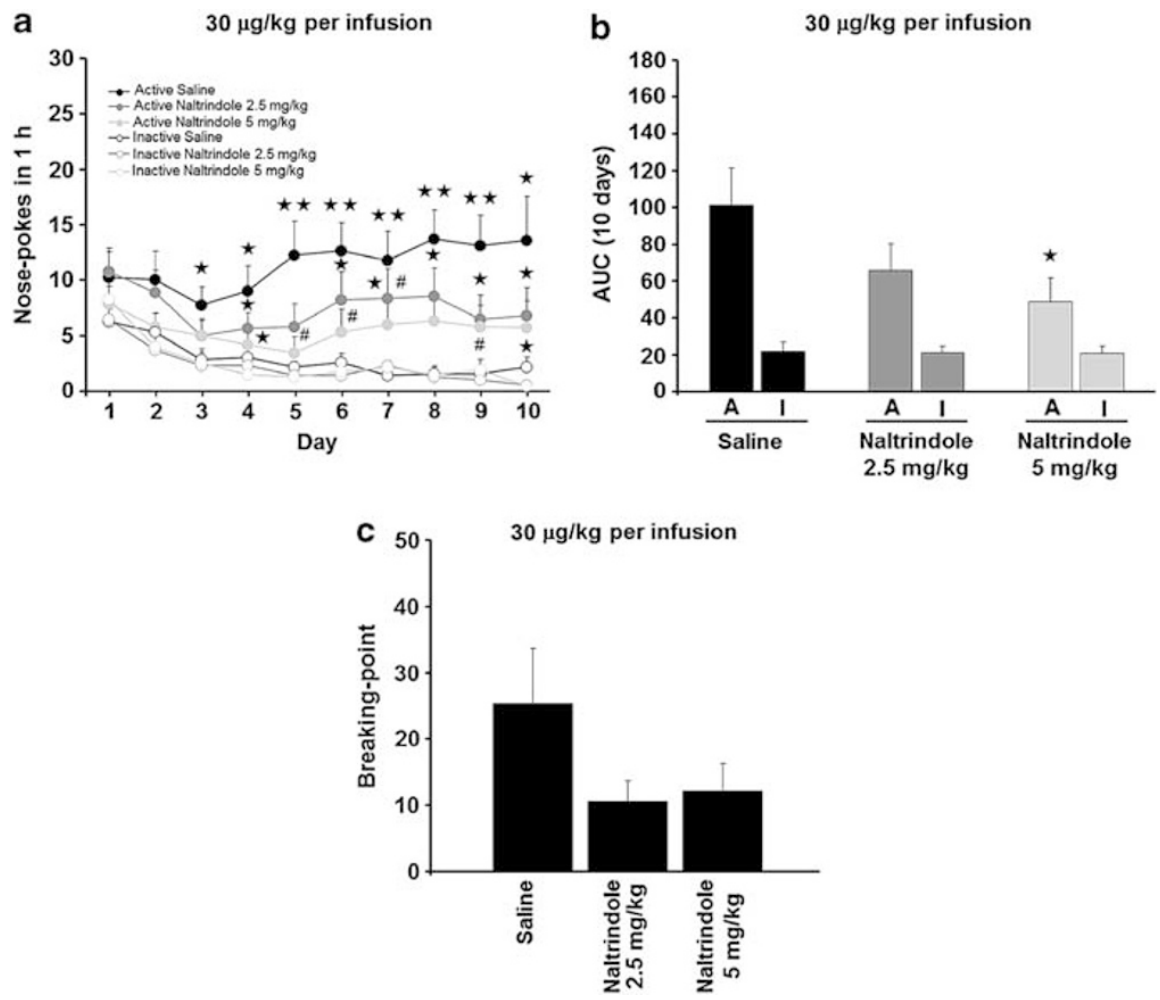

Figure 6 Acquisition of intravenous nicotine self-administration at the dose of $30 \mu \mathrm{g} / \mathrm{kg}$ per infusion in saline- $(n=8)$ and naltrindole-treated $(2.5 \mathrm{mg} / \mathrm{kg}$, i.p., $n=9 ; 5 \mathrm{mg} / \mathrm{kg}$, i.p., $n=10$ ) mice (a). AUC values for the number of infusions during the 10 training sessions in saline- and naltrindole-treated (2.5 and $5 \mathrm{mg} / \mathrm{kg}$, i.p.) mice (b). Breaking-point values achieved in progressive ratio schedule in saline- and naltrindole-treated ( $2.5 \mathrm{and} 5 \mathrm{mg} / \mathrm{kg}$, i.p.) mice (c). Data are expressed as mean \pm SEM. $* p<0.05$, ** $p<0.01$ comparison between holes, ${ }^{\#} p<0.05$ compared with control group in the active hole (a); ${ }^{*} p<0.05$ compared with control group (b) (Fisher LSD test). A, active hole; I, inactive hole. 

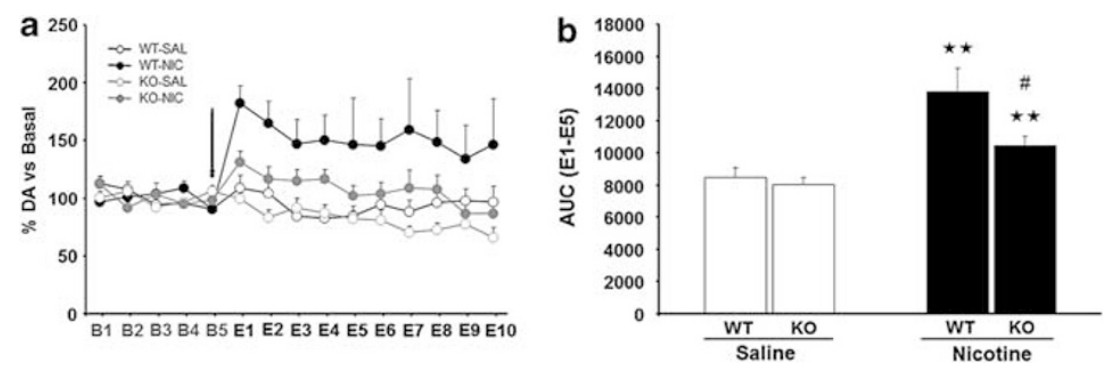

Figure 7 Effects of nicotine $(0.17 \mathrm{mg} / \mathrm{kg}$, s.c.) and saline on dopamine concentrations in dialysates obtained by in-vivo microdialysis from the nucleus accumbens of wild-type and DOR knockout mice. The arrow indicates nicotine or saline administration at time 0 . Dialysate samples were taken every I 8 min during $90 \mathrm{~min}$ before and $180 \mathrm{~min}$ after injection (a). AUC values calculated for the five first samples of the percentage of dopamine concentrations after either nicotine or saline challenge respect to basal concentration in wild-type mice $(n=6-13$ mice per group) and knockout $(n=8-12$ mice per group) animals (b). All values are expressed as mean \pm SEM. ${ }^{*} p<0.0$ I compared with the control group; ${ }^{*} p<0.05$ comparison between genotypes (Fisher LSD test).

a dose-dependent effect of naltrindole treatment in the percentage of active responding (Figure 6a). Control mice showed a stable high preference for the active hole from the third day of training (days 3, 4, and 10, $p<0.05$ and days 5 , $6,7,8,9, p<0.01$ ). Mice treated with $2.5 \mathrm{mg} / \mathrm{kg}$ of naltrindole also exhibited a significant discrimination from day 4 to 10 with exception of day $5(4,6,7,8,9,10, p<0.05)$. However, the preference for the active hole during the whole training period was weaker than in control mice. Finally, mice receiving $5 \mathrm{mg} / \mathrm{kg}$ of naltrindole did not show stable preference for the active hole and the discrimination was only significant on days 4 and $10(p<0.05)$. The total number of infusions earned during the self-administration period expressed as the AUC was also dose-dependently reduced in mice treated with naltrindole (Figure $6 \mathrm{~b}$ ). Thus, two-way ANOVA revealed a significant interaction between hole and treatment $\left(\mathrm{F}_{(2,24)}=3.79, p<0.05\right)$. Subsequent post hoc analysis confirmed that mice treated with $5 \mathrm{mg} / \mathrm{kg}$ of naltrindole obtained a significantly lower number of nicotine infusions than control mice (Figure 6b). Finally, 1 day after the last self-administration session, mice were tested under a progressive ratio schedule of reinforcement. One-way ANOVA did not reveal any significant difference between groups $\left(\mathrm{F}_{(2,24)}=2.15\right.$, n.s. $)$, although a considerable trend to decrease the breaking-point values was observed in mice treated with both doses of naltrindole (2.5 and $5 \mathrm{mg} / \mathrm{kg}$, i.p.) (Figure 6c). Taken together, the results obtained in the nicotine self-administration paradigm with the genetic and pharmacological approaches reveal the role of DOR in the reinforcing properties of nicotine.

\section{Nicotine-Enhanced Extracellular Dopamine Levels in the Nucleus Accumbens Was Attenuated in DOR Knockout Mice}

Acute nicotine administration $(0.17 \mathrm{mg} / \mathrm{kg}$, s.c.) induced an enhancement of dopamine extracellular levels in the nucleus accumbens in both genotypes, although the increase of dopamine was significantly attenuated in mutant animals. This dose of nicotine was chosen considering the reliable enhancement of the dopamine extracellular levels that we observed in previous studies using similar experimental conditions (Berrendero et al, 2005). Three-way ANOVA revealed a significant main effect of time $\left(\mathrm{F}_{(9,306)}=5.06\right.$, $p<0.01)$, treatment $\left(\mathrm{F}_{(1,34)}=13.46, p<0.01\right)$, and genotype
$\left(\mathrm{F}_{(1,34)}=6.13, p<0.05\right)$ after nicotine injection without significant two- or three-way interactions (Figure 7a). AUC values were calculated for the five first samples after nicotine or saline injection. Each AUC value was represented as the sum of percentage of dopamine concentrations after either nicotine or saline challenge respect to basal concentrations (Figure 7b). On the AUC values, twoway ANOVA revealed significant effect of treatment $\left(\mathrm{F}_{(1,35)}=28.81, p<0.01\right)$, genotype $\left(\mathrm{F}_{(1,35)}=7.06, p<0.05\right)$ and interaction between these two factors $\left(\mathrm{F}_{(1,35)}=4.12\right.$, $p<0.05)$. Post hoc analysis revealed a significant effect of nicotine in wild-type $\left(\mathrm{F}_{(1,18)}=17.19, p<0.01\right)$ and knockout mice $\left(\mathrm{F}_{(1,19)}=10.98, \quad p<0.01\right)$, as well as significant differences between wild-type and knockout mice when receiving nicotine $\left(\mathrm{F}_{(1,13)}=5.71, p<0.05\right)$. These results indicate that the deletion of the DOR impaired the effects of nicotine on the extracellular levels of dopamine in the nucleus accumbens.

\section{DISCUSSION}

This study reveals the influence of the deletion of DOR in several nicotine behavioral responses related to its addictive properties. Our results show that DOR modulates the rewarding properties of this drug since nicotine did not induce conditioned place preference in mice lacking DOR and the performance of these mutant mice to obtain nicotine was impaired in an operant paradigm. Moreover, the selective DOR antagonist naltrindole dose-dependently impaired operant nicotine self-administration. In agreement, the enhancement of extracellular levels of dopamine induced by nicotine in the nucleus accumbens was attenuated in DOR knockout mice. In contrast, acute nicotine-induced hypolocomotion and antinociception, as well as the development of tolerance to nicotine antinociceptive effects and nicotine physical dependence were not modified in DOR knockout mice.

Previous reports have shown that enkephalins (Berrendero et al, 2005; Kiguchi et al, 2008) and MOR (Berrendero et al, 2002; Campbell et al, 2006, 2007) participate in nicotine antinociceptive effects. However, the absence of DOR did not modify nicotine-induced antinociception in both the tail-immersion and hot-plate test. Therefore, although endogenous enkephalins are agonists at MOR 
and DOR (Roth-Deri et al, 2008), the present results suggest a prominent role for enkephalins-mediated MOR signaling in the regulation of nicotine antinociceptive effects. In contrast with our results, the DOR antagonist naltrindole at the high dose of $10 \mathrm{mg} / \mathrm{kg}$ blocked the spinal antinociception and attenuated the supraspinal antinociceptive effects induced by nicotine in rats (Campbell et al, 2007). In our experimental conditions, the pretreatment with the same high dose of this antagonist did not modify nicotineinduced antinociception neither in wild-type nor in mutant animals in the tail-immersion test (see Supplementary Figure 1). Therefore, the different animal species (rats $v s$ mice) and methodology used in both studies could explain this discrepancy. Moreover, nicotine-induced hypolocomotion was unaffected by the deletion of DOR, indicating that these receptors do not participate in the acute locomotor effects of nicotine. Previous studies have also reported similar unchanged nicotine-induced hypolocomotion in mice lacking both MOR and the preproenkephalin gene (Berrendero et al, 2002, 2005).

The possible role of DOR in the development of nicotine tolerance and physical dependence was also investigated. The development of tolerance to the antinociceptive effects of nicotine was similar in both genotypes, and chronic nicotine did not produce adaptive changes in the density nor in the functional activity of DOR in the different spinal cord and brain areas evaluated in wild-type tolerant animals. These data show that DOR does not participate in the development of nicotine tolerance, unlike MOR and KOR. Thus, MOR activation of G-proteins was increased in the spinal cord during chronic nicotine treatment in tolerant mice, and MOR knockout mice developed faster tolerance to nicotine antinociception than wild-type animals (Galeote et al, 2006). On the other hand, a decrease in the density of KOR was observed in all layers of the spinal cord in nicotine tolerant mice (Galeote et al, 2008), suggesting that the downregulation of KOR contributes to the development of nicotine tolerance. This idea is based on the requirement of these opioid receptors for a complete manifestation of spinal nicotine antinociception (Galeote et al, 2008). Therefore, the changes occurring during chronic nicotine administration in MOR and KOR seem to play an opposite role in the development of tolerance to nicotine antinociceptive effects, while DOR would not participate in these adaptive changes. Moreover, the deletion of DOR did not modify the somatic signs of the nicotine withdrawal. An increase in preproenkephalin mRNA levels was found in both striatum and hippocampus during nicotine withdrawal in rats (Houdi et al, 1998), as

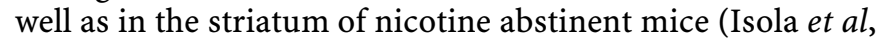
2002). In agreement, the somatic expression of nicotine withdrawal was attenuated by the deletion of proenkephalin (Berrendero et al, 2005) or MOR (Berrendero et al, 2002). Therefore, nicotine physical dependence is regulated by endogenous enkephalins through the activation of MOR. Notably, the negative affective component of nicotine abstinence is also modulated by the endogenous opioid system since high doses of naloxone produced conditioned place aversion in chronically nicotine-treated rodents (Balerio et al, 2004; Ise et al, 2002; Watkins et al, 2000). In the future, it may be of interest to test whether DOR could participate in this affective component of nicotine abstinence since a DOR agonist attenuated the aversive effects of mecamylamine-precipitated nicotine withdrawal (Ise et al, 2000) and a desensitization of DOR was revealed in the nucleus accumbens during spontaneous early nicotine withdrawal (McCarthy et al, 2011).

Nicotine rewarding properties were investigated in DOR knockout mice by using the conditioned place preference and the intravenous self-administration paradigm. Nicotine induced a conditioned place preference in wild-type animals, but this effect was absent in knockout mice. Nicotine-induced conditioned place preference was also blocked in mice lacking MOR or the preproenkephalin gene (Berrendero et al, 2002, 2005), suggesting that endogenous enkephalins through the activation of both MOR and DOR could participate in the rewarding effects of nicotine. DOR has also been reported to be involved in cocaine-induced conditioned place preference (Suzuki et al, 1997; Kotlinska et al, 2010), although this finding was not corroborated by other studies (de Vries et al, 1995). Consistent with the results obtained in the conditioned place preference, the performance in the intravenous nicotine self-administration paradigm was impaired in DOR knockout mice. Thus, at the dose of $15 \mu \mathrm{g} / \mathrm{kg} /$ infusion only $29 \%$ of knockout mice achieved the acquisition criteria in comparison to $70 \%$ of wild-type mice. Similarly, $33 \%$ of knockout and $66 \%$ of wild-type animals acquired the criteria of self-administration at the dose of $30 \mu \mathrm{g} / \mathrm{kg} /$ infusion. In addition, the discrimination between the active and the inactive hole was lower in mutant than in wild-type mice at both doses. A decrease in the number of infusions in the active hole was also found in mice lacking the DOR, mainly at the dose of $30 \mu \mathrm{g} / \mathrm{kg} /$ infusion of nicotine. At this dose of nicotine, the maximal effort required to obtain an infusion of the drug was significantly reduced in DOR knockout mice, suggesting less motivation to seek for nicotine. The impairment of nicotine self-administration in DOR knockout mice cannot be attributed to possible unspecific learning deficits in the acquisition of an operant behavior since these mice maintained operant responding for natural rewards, such as sucrose (Olmstead et al, 2009). A recent report has revealed that the lack of DOR impairs drug-context association (Le Merrer et al, 2011), and this could contribute to the blockade of nicotine conditioned place preference in DOR knockout mice. Importantly, the specific impairment in the acquisition, discrimination, and number of infusions of DOR knockout mice in the nicotine selfadministration paradigm suggests that this opioid receptor directly modulates nicotine reinforcing properties.

The impairment in nicotine self-administration revealed in DOR knockout mice was not due to compensatory mechanisms since similar results were obtained in wild-type mice treated with the selective DOR antagonist naltrindole. Indeed, naltrindole treatment dose-dependently impaired nicotine self-administration in wild-type mice since only 33 and $10 \%$ of mice treated with naltrindole $(2.5$ and $5 \mathrm{mg} / \mathrm{kg}$, respectively), acquired the criteria of nicotine $(30 \mu \mathrm{g} / \mathrm{kg} /$ infusion) self-administration in comparison to $62.5 \%$ of control animals. The percentage of active responding and the number of infusions in the active hole were also significantly reduced due to the naltrindole treatment. In contrast with our results, this DOR antagonist did not modify i.v. nicotine self-administration in rats (Liu and 
Jernigan, 2011), although a clear tendency to decrease this rat self-administration behavior was found in a previous study (Ismayilova and Shoaib, 2010). The different animal species used in these studies could explain this discrepancy. The non-selective opioid antagonist naloxone robustly reduced nicotine self-administration (Ismayilova and Shoaib, 2010) and a possible participation of the three opioid receptor subtypes in this nicotine effect was suggested. On the other hand, different results have been obtained in the case of other drugs of abuse since a preservation of morphine self-administration (Le Merrer et al, 2011) or an enhanced voluntary ethanol consumption (Roberts et al, 2001) were reported in DOR knockout mice. Moreover, addition of the DOR agonist SNC80 to heroin did not enhance the reinforcing effects of heroin (Stevenson et al, 2005). Therefore, the overall role of DOR in drug reward and addiction is complex (Pradhan et al, 2011), and future studies will be required to clarify this important issue.

Nicotine, like most drugs of abuse, produces a stimulation of dopamine transmission in the nucleus accumbens that is related to its rewarding properties (Di Chiara and Imperato, 1988). Nicotine activates the mesolimbic system through a direct effect on the ventral tegmental area dopamine neurons, but also by modifying the functional balance between the excitatory (glutamatergic neurons) and inhibitory (GABAergic neurons) inputs on these dopamine neurons (Mansvelder and McGehee, 2002). Previous studies have demonstrated that the activation of MOR (Maisonneuve and Glick, 1999; Tanda and Di Chiara, 1998) by peptides derived from preproenkephalin (Berrendero et al, 2005 ) is necessary to obtain an increase in the extracellular levels of dopamine in the nucleus accumbens after nicotine administration. This opioid-dependent mechanism would be important to remove the inhibitory inputs on ventral tegmental area dopamine neurons finally increasing their firing rate in vivo (Berrendero et al, 2005). According to the present behavioral findings, our in-vivo microdialysis experiments showed that the enhancement in dopamine efflux in the nucleus accumbens induced by nicotine in wild-type mice was significantly attenuated in DOR knockout animals. Both the striatum and the nucleus accumbens show a high density of DOR (Pradhan et al, 2011), and the activation of DOR in the nucleus accumbens (Longoni et al, 1991; Hipólito et al, 2008) has been reported to enhance extracellular dopamine levels in this brain area, which contains a high level of enkephalin expressing cells (Svingos et al, 1998). Therefore, the activation of DOR by endogenous enkephalins would participate in the enhancement of dopamine extracellular levels in the nucleus accumbens promoted by nicotine administration, which has been related to the rewarding properties of this drug of abuse (Di Chiara and Imperato, 1988). The facilitatory effects on dopamine transmission induced by DOR located in the nucleus accumbens (Longoni et al, 1991; Hipólito et al, 2008) would explain the involvement of DOR in nicotine rewarding effects.

In conclusion, this study reveals the regulatory role of DOR in the rewarding properties of nicotine and its effects on the extracellular levels of dopamine in the nucleus accumbens. However, this opioid receptor subtype would not participate in the acute effects of nicotine on nociception and locomotion nor in the development of nicotine antinociceptive tolerance and physical dependence. These findings provide new information about the involvement of this specific component of the endogenous opioid system in behavioral and biochemical effects of nicotine related to its addictive properties, which could help to develop more rational therapeutic strategies to treat tobacco smoking.

\section{ACKNOWLEDGEMENTS}

This work was supported by the Spanish "Ministerio de Ciencia e Innovación" (\#SAF2007-64062 and \#SAF-201129864), the "Instituto de Salud Carlos III" Grants \#PI07/0559, \#PI10/00316, and \#RD06/001/001, the "Plan Nacional Sobre Drogas" (\#2009/026), the Catalan Government (SGR200900131), and the ICREA Foundation (ICREA Academia Award-2008) to RM. Partial support of FEDER funds is also acknowledged.

\section{DISCLOSURE}

The authors declare no conflict of interest.

\section{REFERENCES}

Balerio GN, Aso E, Berrendero F, Murtra P, Maldonado R (2004). Delta9-tetrahydrocannabinol decreases somatic and motivational manifestations of nicotine withdrawal in mice. Eur $J$ Neurosci 20: 2737-2748.

Balerio GN, Aso E, Maldonado R (2005). Involvement of the opioid system in the effects induced by nicotine on anxiety-like behavior in mice. Psychopharmacology (Berl) 181: 260-269.

Berrendero F, Kieffer BL, Maldonado R (2002). Attenuation of nicotine-induced antinociception, rewarding effects, and dependence in mu-opioid receptor knock-out mice. J Neurosci 22: 10935-10940.

Berrendero F, Mendizabal V, Robledo P, Galeote L, Bilkei-Gorzo A, Zimmer A et al (2005). Nicotine-induced antinociception, rewarding effects, and physical dependence are decreased in mice lacking the preproenkephalin gene. J Neurosci 25: 1103-1112.

Berrendero F, Robledo P, Trigo JM, Martín-García E, Maldonado R (2010). Neurobiological mechanisms involved in nicotine dependence and reward: participation of the endogenous opioid system. Neurosci Biobehav Rev 35: 220-231.

Brüning CA, Prigol M, Roehrs JA, Zeni G, Nogueira CW (2010). Evidence for the involvement of $\mu$-opioid and $\delta$-opioid receptors in the antinociceptive effect caused by oral administration of m-trifluoromethyl-diphenyl diselenide in mice. Behav Pharmacol 21: 621-626.

Campbell VC, Taylor RE, Tizabi Y (2006). Antinociceptive effects of alcohol and nicotine: involvement of the opioid system. Brain Res 1097: 71-77.

Campbell VC, Taylor RE, Tizabi Y (2007). Effects of selective opioid receptor antagonists on alcohol-induced and nicotineinduced antinociception. Alcohol Clin Exp Res 31: 1435-1440.

Castañé A, Valjent E, Ledent C, Parmentier M, Maldonado R, Valverde O (2002). Lack of CB1 cannabinoid receptors modifies nicotine behavioural responses, but not nicotine abstinence. Neuropharmacology 43: 857-867.

Ciccocioppo R, Martin-Fardon R, Weiss F (2002). Effect of selective blockade of $\mathrm{mu}(1)$ or delta opioid receptors on reinstatement of alcohol-seeking behavior by drug-associated stimuli in rats. Neuropsychopharmacology 27: 391-399. 
Dani JA, Balfour DJ (2011). Historical and current perspective on tobacco use and nicotine addiction. Trends Neurosci 34: 383-392. de Vries J, Babovic-Vuksanovic D, Elmer G, Shippenberg TS (1995). Lack of involvement of delta-opioid receptors in mediating the rewarding effects of cocaine. Psychopharmacology (Berl) 120: 442-448.

Di Chiara G, Imperato A (1988). Drugs abused by humans preferentially increase synaptic dopamine concentrations in the mesolimbic system of freely moving rats. Proc Natl Acad Sci USA 85: 5274-5278.

Filliol D, Ghozland S, Chluba J, Martin M, Matthes HW, Simonin F et al (2000). Mice deficient for delta- and mu-opioid receptors exhibit opposing alterations of emotional responses. Nat Genet 25: $195-200$.

Galeote L, Kieffer BL, Maldonado R, Berrendero F (2006). Muopioid receptors are involved in the tolerance to nicotine antinociception. J Neurochem 97: 416-423.

Galeote L, Maldonado R, Berrendero F (2008). Involvement of kappa/dynorphin system in the development of tolerance to nicotine-induced antinociception. J Neurochem 105: 1358-1368.

Galeote L, Berrendero F, Bura SA, Zimmer A, Maldonado R (2009). Prodynorphin gene disruption increases the sensitivity to nicotine self-administration in mice. Int J Neuropsychopharmacol 12: 615-625.

Gibaldi M, Perrier D (1975). The trapezoid rule. In: Gibaldi M, Perier D (eds), pp. Pharmacokinetics. Marcel Dekker: New York. pp. 293-296.

Göktalay G, Cavun S, Levendusky MC, Hamilton JR, Millington WR (2006). Glycyl-glutamine inhibits nicotine conditioned place preference and withdrawal. Eur J Pharmacol 530: 95-102.

Goody RJ, Oakley SM, Filliol D, Kieffer BL, Kitchen I (2002). Quantitative autoradiographic mapping of opioid receptors in the brain of delta-opioid receptor gene knockout mice. Brain Res 945: 9-19.

Hadjiconstantinou M, Neff NH (2011). Nicotine and endogenous opioids: neurochemical and pharmacological evidence. Neuropharmacology 60: 1209-1220.

Hipólito L, Sánchez-Catalán MJ, Zanolini I, Polache A, Granero L (2008). Shell/core differences in mu- and delta-opioid receptor modulation of dopamine efflux in nucleus accumbens. Neuropharmacology 55: 183-189.

Houdi AA, Dasgupta R, Kindy MS (1998). Effect of nicotine use and withdrawal on brain preproenkephalin A mRNA. Brain Res 799: 257-263.

Ise Y, Narita M, Nagase $H$, Suzuki $T$ (2000). Modulation of opioidergic system on mecamylamine-precipitated nicotine-withdrawal aversion in rats. Psychopharmacology (Berl) 151: 49-54.

Ise Y, Narita M, Nagase H, Suzuki T (2002). Modulation of kappaopioidergic systems on mecamylamine-precipitated nicotinewithdrawal aversion in rats. Neurosci Lett 323: 164-166.

Ismayilova N, Shoaib M (2010). Alteration of intravenous nicotine self-administration by opioid receptor agonist and antagonists in rats. Psychopharmacology (Berl) 210: 211-220.

Isola R, Zhang $\mathrm{H}$, Duchemin AM, Tejwani GA, Neff $\mathrm{NH}$, Hadjiconstantinou M (2002). Met-enkephalin and preproenkephalin mRNA changes in the striatum of the nicotine abstinence mouse. Neurosci Lett 325: 67-71.

Kiguchi N, Maeda T, Tsuruga M, Yamamoto A, Yamamoto C, Ozaki M et al (2008). Involvement of spinal Met-enkephalin in nicotine-induced antinociception in mice. Brain Res 1189: 70-77.

King A, de Wit H, Riley RC, Cao D, Niaura R, Hatsukami D (2006). Efficacy of naltrexone in smoking cessation: a preliminary study and an examination of sex differences. Nicotine Tob Res 8: 671-682.

Kitchen I, Slowe SJ, Matthes HW, Kieffer BL (1997). Quantitative autoradiographic mapping of mu-, delta- and kappa-opioid receptors in knockout mice lacking the mu-opioid receptor gene. Brain Res 778: 73-88.
Kotlinska JH, Gibula-Bruzda E, Pachuta A, Kunce D, Witkowska E, Chung NN et al (2010). Influence of new deltorphin analogues on reinstatement of cocaine-induced conditioned place preference in rats. Behav Pharmacol 21: 638-648.

Le Merrer J, Plaza-Zabala A, Del Boca C, Matifas A, Maldonado R, Kieffer BL (2011). Deletion of the $\delta$ opioid receptor gene impairs place conditioning but preserves morphine reinforcement. Biol Psychiatry 69: 700-703.

Liu X, Jernigan C (2011). Activation of the opioid $\mu 1$, but not $\delta$ or $\kappa$, receptors is required for nicotine reinforcement in a rat model of drug self-administration. Prog Neuropsychopharmacol Biol Psychiatry 35: 146-153.

Longoni R, Spina L, Mulas A, Carboni E, Garau L, Melchiorri P et al (1991). (D-Ala2)deltorphin II: D1-dependent stereotypies and stimulation of dopamine release in the nucleus accumbens. J Neurosci 11: 1565-1576.

Maisonneuve IM, Glick SD (1999). (+/-)Cyclazocine blocks the dopamine response to nicotine. Neuroreport 10: 693-696.

Maldonado R, Saiardi A, Valverde O, Samad TA, Roques BP, Borrelli E (1997). Absence of opiate rewarding effects in mice lacking dopamine D2 receptors. Nature 388: 586-589.

Mansour A, Khachaturian H, Lewis ME, Akil H, Watson SJ (1987). Autoradiographic differentiation of mu, delta, and kappa opioid receptors in the rat forebrain and midbrain. $J$ Neurosci 7: 2445-2464

Mansvelder HD, McGehee DS (2002). Cellular and synaptic mechanisms of nicotine addiction. J Neurobiol 53: 606-617.

Martín-García E, Barbano MF, Galeote L, Maldonado R (2009). New operant model of nicotine-seeking behaviour in mice. Int $J$ Neuropsychopharmacol 12: 343-356.

McCarthy MJ, Zhang H, Neff NH, Hadjiconstantinou M (2011). Desensitization of $\delta$-opioid receptors in nucleus accumbens during nicotine withdrawal. Psychopharmacology (Berl) 213: 735-744.

Molander C, Xu Q, Grant G (1984). The cytoarchitectonic organization of the spinal cord in the rat. I. The lower thoracic and lumbosacral cord. J Comp Neurol 230: 133-141.

Olmstead MC, Ouagazzal AM, Kieffer BL (2009). Mu and delta opioid receptors oppositely regulate motor impulsivity in the signaled nose poke task. PLoS One 4: e4410.

Paxinos G, Franklin KBJ (1997). The Mouse Brain in Stereotaxic Coordinates. Academic: San Diego.

Plaza-Zabala A, Martín-García E, de Lecea L, Maldonado R, Berrendero F (2010). Hypocretins regulate the anxiogenic-like effects of nicotine and induce reinstatement of nicotine-seeking behavior. J Neurosci 30: 2300-2310.

Pradhan AA, Clarke PB (2005). Comparison between delta-opioid receptor functional response and autoradiographic labeling in rat brain and spinal cord. J Comp Neurol 481: 416-426.

Pradhan AA, Befort K, Nozaki C, Gavériaux-Ruff C, Kieffer BL (2011). The delta opioid receptor: an evolving target for the treatment of brain disorders. Trends Pharmacol Sci 32: 581-590.

Roberts AJ, Gold LH, Polis I, McDonald JS, Filliol D, Kieffer BL et al (2001). Increased ethanol self-administration in delta-opioid receptor knockout mice. Alcohol Clin Exp Res 25: 1249-1256.

Roth-Deri I, Green-Sadan T, Yadid G (2008). Beta-endorphin and drug-induced reward and reinforcement. Prog Neurobiol 86: $1-21$.

Shippenberg TS, LeFevour A, Chefer VI (2008). Targeting endogenous mu- and delta-opioid receptor systems for the treatment of drug addiction. CNS Neurol Disord Drug Targets 7: 442-453.

Sim LJ, Selley DE, Childers SR (1995). In vitro autoradiography of receptor-activated $\mathrm{G}$ proteins in rat brain by agonist-stimulated guanylyl 5'-[gamma-[35S]thio]-triphosphate binding. Proc Natl Acad Sci USA 92: 7242-7246.

Simonin F, Valverde O, Smadja C, Slowe S, Kitchen I, Dierich A et al (1998). Disruption of the kappa-opioid receptor gene in 
$\delta$-Opioid receptor and nicotine

F Berrendero et al

mice enhances sensitivity to chemical visceral pain, impairs pharmacological actions of the selective kappa-agonist $\mathrm{U}-50,488 \mathrm{H}$ and attenuates morphine withdrawal. EMBO J 17: 886-897.

Soria G, Mendizábal V, Touriño C, Robledo P, Ledent C, Parmentier M et al (2005). Lack of CB1 cannabinoid receptor impairs cocaine self-administration. Neuropsychopharmacology 30: $1670-1680$.

Stevenson GW, Folk JE, Rice KC, Negus SS (2005). Interactions between delta and mu opioid agonists in assays of schedulecontrolled responding, thermal nociception, drug self-administration, and drug versus food choice in rhesus monkeys: studies with SNC80 [(+)-4-[(alphaR)-alpha-((2S,5R)-4-allyl-2,5-dimethyl-1-piperazinyl)-3-methoxybenzyl]-N,N-diethylbenzamide] and heroin. J Pharmacol Exp Ther 314: 221-231.

Suzuki T, Tsuji M, Ikeda H, Misawa M, Narita M, Tseng LF et al (1997). Antisense oligodeoxynucleotide to delta opioid receptors blocks cocaine-induced place preference in mice. Life Sci 60: 283-288.

Supplementary Information accompanies the paper on the Neuropsychopharmacology website (http://www.nature.com/npp)
Svingos AL, Clarke CL, Pickel VM (1998). Cellular sites for activation of delta-opioid receptors in the rat nucleus accumbens shell: relationship with Met5-enkephalin. J Neurosci 18: 1923-1933.

Tanda G, Di Chiara G (1998). A dopamine-mul opioid link in the rat ventral tegmentum shared by palatable food (Fonzies) and nonpsychostimulant drugs of abuse. Eur J Neurosci 10: 1179-1187.

Trigo JM, Zimmer A, Maldonado R (2009). Nicotine anxiogenic and rewarding effects are decreased in mice lacking betaendorphin. Neuropharmacology 56: 1147-1153.

Walsh Z, Epstein A, Munisamy G, King A (2008). The impact of depressive symptoms on the efficacy of naltrexone in smoking cessation. J Addict Dis 27: 65-72.

Walters CL, Cleck JN, Kuo YC, Blendy JA (2005). Mu-opioid receptor and CREB activation are required for nicotine reward. Neuron 46: 933-943.

Watkins SS, Stinus L, Koob GF, Markou A (2000). Reward and somatic changes during precipitated nicotine withdrawal in rats: centrally and peripherally mediated effects. J Pharmacol Exp Ther 292: 1053-1064. 